\title{
AUDIT SISTEM INFORMASI AKUNTANSI BERBASIS KOMPUTER UNTUK FINANCIAL REPORT
}

\author{
Peniarsih \\ Universitas Dirgantara Marsekal Suryadarma \\ ppeniarsih@yahoo.co.id
}

\begin{abstract}
By processing transactions that already use computers, namely Computer-Based Accounting Information Systems. The accounting process carried out for processing transactions / data, enough users / users only by entering data / transactions, so that the data will automatically be integrated and can make up to date Financial Report information. To keep the system reliable and trustworthy, it is necessary to audit a computer-based accounting information system so that financial reports produce information that is relevant, timely, accurate, complete and summarized. Finannial report, up to date, relevant, audit.
\end{abstract}

Keyword: Audit, Sistem Informasi. Akuntani, Financial Report

Abstrak
Dengan pengolahan transaksi yang sudah menggunakan komputer yaitu Sistem
Informasi Akuntansi Berbasis Komputer. Proses akuntansi yang dilakukan untuk
pengolahan transaksi/data, cukup user/pemakai tersebut hanya dengan menginput
data/transaksi, sehingga secara otomatis data tersebut akan terintegrasi dan bias
membuat informasi Financial Report yang up to date. Untuk menjaga agar system
tersebut dapat diandalkan dan dapat dipercaya, maka perlu Audit Sistem Informasi
Akuntansi Berbasis Komputer sehingga Financial Report menghasilkan informasi yang
relevan, tepat waktu, akurat, lengkap dan merupakan rangkuman. Finanncial report, up
to date, relevan, audit.

Kata Kunci : Audit, Sistem Informasi. Akuntani, Financial Report

\section{PENDAHULUAN}

Pengolahan informasi dalam penyajian Financial Report semakin banyak dipergunakan sebagai alat bantu dalam menyajikan informasi yang relevan. Hal ini dapat diketahui sejak dikenalkan dan digunakannya peralatan computer dalam bidang komersial kira-kira 20 tahun yang lalu, hingga hampir seluruh aktivitas pemrosesan data dan Informasi Keuangan 
dalam suatu Perusahaan, Perusahaan dan Instansi Pemerintah dari pencatatan transaksi, penggolongan, perekaman data, perhitungan sampai pada Financial Report dilakukan dengan menggunakan peralatan komputer.

Dengan kemajuan teknologi di dunia usaha yang terus menerus, Sistem Informasi Akuntansi yang dikerjakan secara manual sekarang dapat dilakukan dengan bantuan komputer yaitu Sistem Informasi Akuntansi berbasis komputer. Proses dalam akuntansi secara manual dan berbasis komputer tidak jauh beda, yang membedakan dalam Sistem Informasi berbasis komputer dapat dilakukan dengan sekali entry (input) data atau transaksi saja, hal ini dalam buku besar akan berubah dan secara langsung dapat merubah Financial Report juga.

Sering kali pegawai yang menangani pemrosesan pertama dalam input data pada transaksi - transaksi tidak pernah melihat hasil akhirnya, ini dapat memungkinkan adanya kekeliruan dalam Sistem Informasi Akuntansi. Hal ini disebabkan adanya suatu anggapan bahwa informasi hasil keluaran computer selalu benar, maka dalam input data (entry data) diperlukan suatu pengawasan atau pengendalian. Tidak hanya entry data saja dalam proses dan hasil output berupa Informasi Akuntansi harus adanya suatu pengendalian atau pengawasan sehingga dapat memberikan informasi yang benar-benar dapat dipergunakan oleh pihak manajemen atau pihak lainnya.

Informasi Financial Report merupakan suatu alat bantu bagi manajemen sebagai dasar pengambilan keputusan untuk membuat suatu strategi dalam menghadapi persaingan yang semakin ketat dan juga untuk membuat suatu rencana bagi perusahaan di masa yang akan datang, informasi Financial Report juga merupakan informasi bagi pihak ekstern/luar perusahaan (pemegang saham, investor dan lain-lain).

Audit atau pemeriksaan dalam arti luas bermakna evaluasi terhadap suatu organisasi, sistem, proses, atau produk. Audit dilaksanakan oleh pihak yang kompeten, objektif, dan tidak memihak, yang disebut auditor.

Audit Sistem Informasi Akuntansi berbasis komputer dapat memberikan masukan mengenai baik buruknya suatu Sistem Informasi Akuntansi, mulai dari input data, proses dan outputnya. Di mana suatu informasi mempunyai karakteristik sebagai berikut: relevan, tepat waktu, akurat, lengkap dan merupakan rangkuman. Dengan dukungan Audit Sistem Informasi Akuntansi berbasis komputer dapat memberikan masukan terhadap suatu perusahaan dengan daya saji informasi Financial Report yang sesuai dengan karakteristik tadi dan dapat mengetahui kemungkinan adanya salah saji informasi. 


\section{LANDASAN TEORI}

Audit "Suatu proses sistematik untuk memperoleh dan mengevaluasi bukti secara objektif mengenai pernyataanpernyataan tentang kegiatan dan kejadian ekonomi, dengan tujuan untuk menetapkan tingkat kesesuaian antara pernyataanpernyataan tersebut dengan kriteria-kriteria yang telah ditetapkan, serta menyampaikan hasilhasilnya kepada pemakai yang berkepentingan.” ( Mulyadi, 2002) Sistem Informasi Akuntansi "Sekelompok dua atau lebih komponenkomponen yang saling berkaitan (interrelated) atau subsistem-subsistem yang bersatu untuk mencapai tujuan yang sama (common purpose)." (Hall, 2001).

\section{Uraian :}

a. Hanya melibatkan proses dengan tangan manusia dalam kegiatan key in transaksi (mencatat dokumentasi bisnis) ke dalam media komputer.

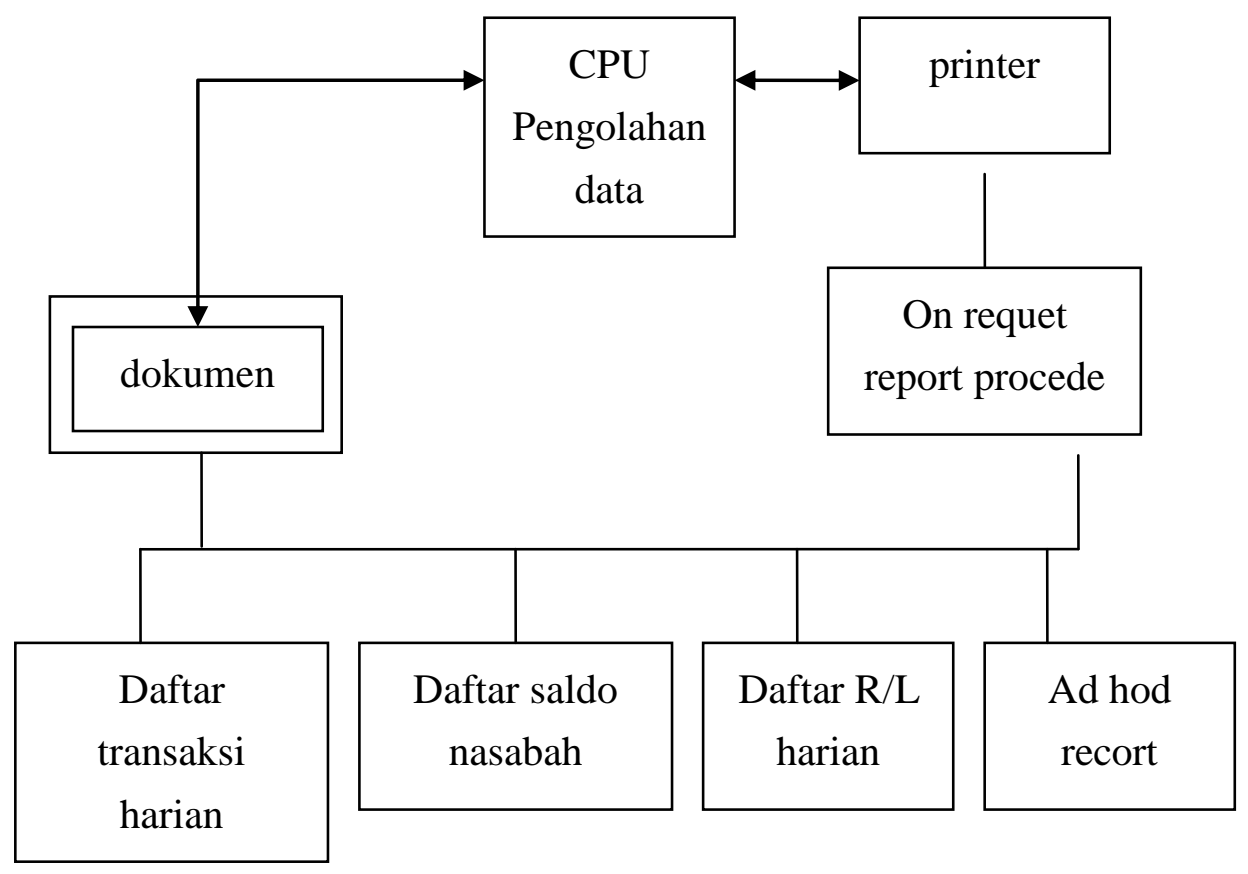

\section{Gambar 1}

Proses akuntansi secara komputerisasi

b. Kecermatan dengan ketepatan waktu pencatatan dan informasi penyajian keuangan terjamin oleh komputer.

c. Unsur yang paling kritis adalah program komputer yang digunakan dalam memproses kegiatan akuntansi.
Financial Report "Laporan yang dirancang untuk para pembuat keputusan, terutama pihak luar perusahaan, mengenai posisi keuangan dan hasil usaha perusahaan." (Sumarso, 1995). Dalam bidang pemeriksaan akuntansi (auditing), akuntan 
tidak dapat lagi menerapkan metode pemeriksaan lama dalam lingkungan organisasi yang telah menggunakan komputer. Ada tiga pendekatan yang dapat dilakukan oleh akuntan dalam memeriksa Financial Report yang telah menggunakan Sistem Informasi Akuntansi adalah:

1. Auditing Around The Computer Pendekatan ini merupakan pendekatan yang mula - mula ditempuh oleh akuntan. Asumsi yang digunakan dalam pendekatan ini adalah apabila sampel keluaran dari suatu system ternyata benar berdasarkan masukan system tadi, maka pemrosesannya tentunya dapat diandalkan. Dalam pemeriksaan dengan pendekatan ini akuntan melakukan pemeriksaan di sekitar komputer saja.

2. Auditing With The Komputer Dengan pendekatan ini, akuntan telah memanfaatkan komputer sebagai alat dalam melakukan pemeriksaan. Pada bentuk yang sederhana, komputer dilakukan sebagai alat untuk melakukan penulisan, perhitungan, perbandingan dan sebagainya. Bentuk yang lebih maju dalam pendekatan ini adalah digunakannya Generalized Audit Software yaitu program audit yang berlaku umum untuk berbagai klien.

3. Auditing Through The Computer Dalam pendekatan ini, akuntan tidak lagi $=$ Data/voucher Sistem .

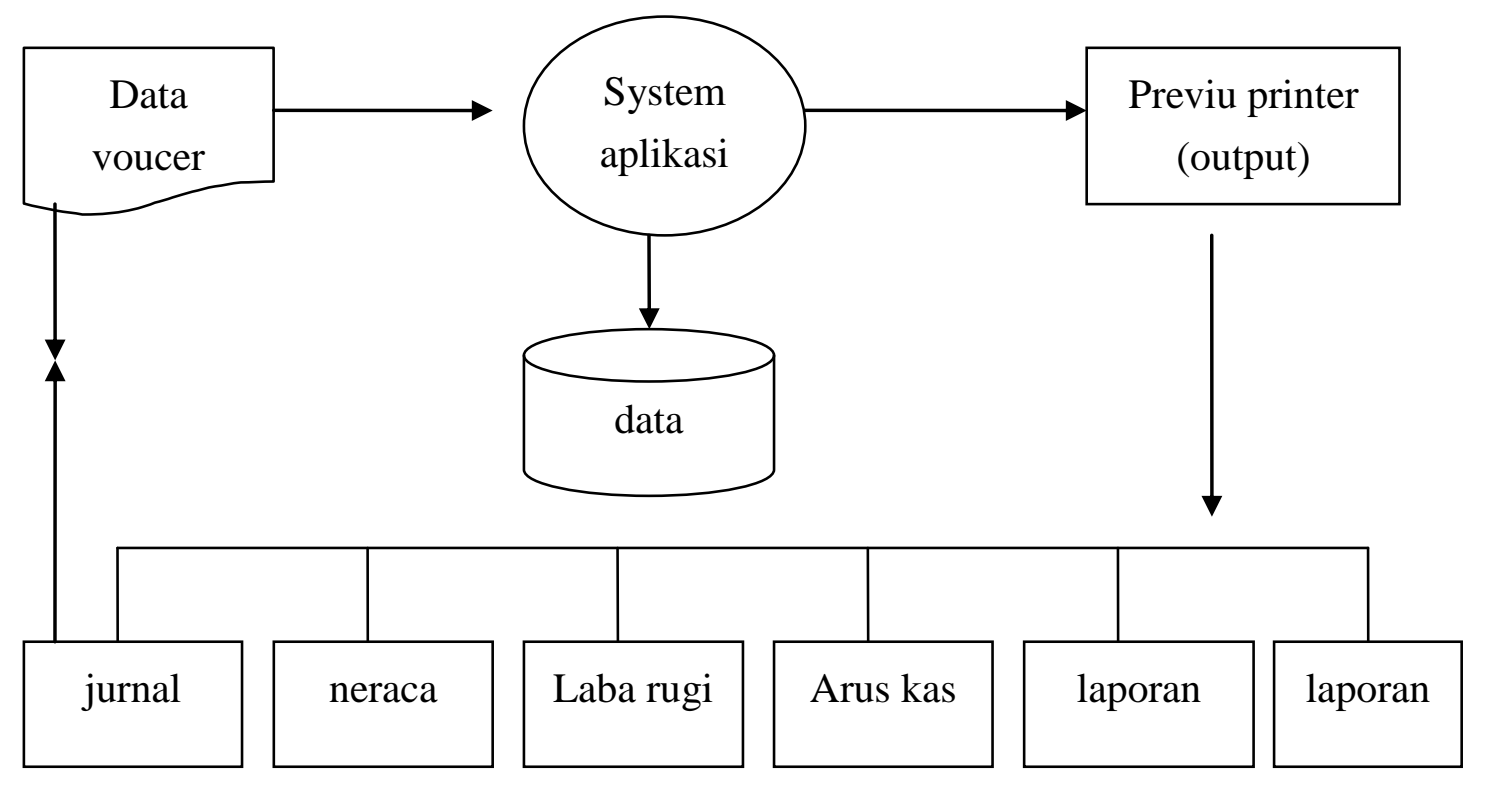

Gambar 2. Proses akuntansi secara komputerisasi

Sumber: Lapoliwa \& Daniel (1997). memperlakukan komputer sebagai black box.

Di sini akuntan memasukkan data ke dalam komputer untuk diproses hasilnya, kemudian dianalisis untuk memeriksa keandalan dan kecermatan program komputer tersebut. 


\section{HASIL DAN PEMBAHASAN}

Penelitian dengan Audit Sistem Informasi Akuntansi berbasis Komputer harus ada masukan/input data dalam suatu sistem. Kemudian untuk memeriksa Financial Report dilakukan dengan cara terbalik di mana dilakukan pada Financial Report kemudian dilakukan periksaan terhadap aplikasi sampai dengan data/inputan data bisa dilihat pada Gambar 2.

Uraian proses akuntansi di atas :

1. Data/voucher, merupakan catatan pertama dari setiap transaksi yang akan digunakan sebagai dasar menginput.

2. Data/voucher diproses dalam sistem.

3. Setelah diproses, sistem mengoutput data menjadi informasi.

4. Output tersebut adalah Jurnal, Neraca, Laba/Rugi, Arus Kas, Laporan Audit dan lain-lain.

5. Di mana data/voucher yang diinput jumlahnya harus sama dengan hasil output Jurnal.

6. Hasil proses disimpan.

7. Input/voucher pada waktu input data harus sama (jumlahnya) dengan output (Jurnal).

Dalam pengolahan transaksi dengan komputerisasi, seluruh proses kegiatan mulai dari Jurnal, Buku Besar, Neraca dan lain-lain dikerjakan oleh sistem aplikasi, di mana sistem aplikasi yang akan memproses semua data/voucher dengan cepat, cermat dan lengkap. Sistem aplikasi tersebut dapat memberikan Financial Report secara cepat dengan criteria atau standar penyajian Laporan Keuangan, Financial Report tersebut merupakan kebutuhan manajemen yang mutlak dipenuhi oleh perusahaan.

Penyajian Financial Report pada perusahaan, diperlukan suatu Sistem Informasi Akuntansi yang efektif yang dapat memenuhi informasi bagi pihak intern maupun ekstern yang up to date, dengan Sistem Informasi Akuntansi berbasis komputer harus mampu mengatasi permasalahan informasi Financial Report dalam perusahaan.

\section{Uji Hipotesis}

Untuk mengujinya menggunakan rumus spearman brown, dengan $r b=0,823$ dimasukkan dan perhitungannya sebagai berikut: Maka hasil dari sperman brown adalah 0,902 kemudian untuk mencari instrumen tersebut reliablitas atau tidak yaitu dengan membandingkan antara r-hitung dan r-tabel. Di mana taraf kesalahan/significant adalah 0,05 atau 0,01. Diperoleh rtabel $0,05=0,444$ atau rtabel $0,01=0,561$ dan rhitung $=0,902$, karena rhitung lebih besar dari pada rtabel untuk taraf kesalahan/significant 0,05 maupun $0,01(0,902>0,561>0,444)$. Maka disimpulkan seluruh instrumen tersebut dikatakan reliabelitas.

\section{MSI (Method Of Sucessive Interval)}

Karena skala yang digunakan dalam 
penelitian ini yaitu ordinal, maka diubah dari skala ordinal menjadi skala interval yang langkahnya :

a. Perhatikan (f) responden (banyaknya responden yang memberikan respons yang ada).

b. Bagi setiap bilangan pada (f) oleh (n).

c. Jumlahkan (p)secara berurutan setiap respons dan keluar (pk).

d. Proporsi kumulatif (pk) dianggap mengikuti distribusi normal baku.

e. Hitung SV (Scale Value = nilai skala).

f. SV (Scale Value) yang nilainya terkecil (harga negatif yang terbesar) diubah menjadi satu (1).

Hasil MSI lihat di lampiran, di mana hasil dari keduanya dipisahkan menjadi variabel $\mathrm{X}$ dan $\mathrm{Y}$. Di mana skor variabel $\mathrm{X}$ dan $\mathrm{Y}$ dicari korelasinya menggunakan analisis korelasi sederhana pearson, dengan tabel penolong (MSI), hasil korelasinya yaitu 0,597 .

\section{Korelasi Sederhana Dan Koefisien Determinasi}

Analisis yang digunakan adalah dengan menggunakan koefisien korelasi person di mana hasil dari jawaban responden variabel $\mathrm{X}$ dan variabel $\mathrm{Y}$ dicari skornya, kemudian dikorelasikan yang hasilnya adalah Di mana 0,591 nantinya dimasukkan pada statistik uji hipotesis. Maka untuk menentukan keeratan hubungan kedua variable bias menggunakan kriteria Guilford.
Dari hasil koefisien korelasi person di atas, dapat diketahui bahwa nilai korelasi Peranan Audit Sistem Informasi Akuntansi Berbasis Komputer dan Penyajian Financial Report sebesar 0,591. Nilai 0,591 artinya antara korelasi Peranan Audit Sistem Informasi Akuntansi Berbasis Komputer mempunyai peranan dalam Penyajian Laporan Keuangan, di mana apabila semakin baiknya suatu Audit Sistem Informasi Akuntansi Berbasis Komputer semakin baik juga dalam penyajian Laporan Keuangan. Hubungan ini menurut aturan Guilford menunjukkan hubungan yang cukup.

Setelah diketahui koefisien Korelasi Pearson dengan variabel $\mathrm{X}$ dan variabel $\mathrm{Y}$, selanjutnya kita uji lagi dengan koefisien determinasi. Koefisien determinasi adalah kuadrat koefisien korelasi yang menyatakan besarnya persentase perubahan $\mathrm{Y}$ yang bisa diterangkan oleh $\mathrm{X}$ melalui hubungan $\mathrm{Y}$ dengan $\mathrm{X}$, di mana perhitungannya sebagai berikut: Dengan koefisien determinasinya adalah $59,1 \%$ hal ini menjelaskan bahwa Peranan Audit Sistem Informasi Akuntansi Berbasis Komputer adalah sebesar $59,1 \%$ dan sisanya, yaitu $100 \%-59,1 \%=40,9 \%$ dijelaskan oleh variabel lain, misalnya terjadi kerusakan pada sistem informasi (BOSS) dan pemakai (user) tidak dapat memperbaikinya, sehingga terjadi keterlambatan dalam penyajian informasi Laporan Keuangan. 


\section{Hipotesis}

Untuk mengetahui keeratan hubungan antara variabel $\mathrm{X}$ dan variabel $\mathrm{Y}$, yaitu dengan menggunakan analisis korelasi sederhana dengan menggunakan software SPSS 10.0.5 for windows, yang langkah kerjanya sebagai berikut:

\section{a. Hipotesis}

Ho : Audit Sistem Informasi Akuntansi Berbasis Komputer Tidak Mempunyai

Peranan Dalam Penyajian Laporan Keuangan.

H1 : Audit Sistem Informasi Akuntansi Berbasis Komputer Mempunyai Peranan Dalam Penyajian Laporan Keuangan.

$r=0,591$.

0,00 - 0,20 Hubungan yang sangat kecil

0,20 - 0,40 Hubungan yang kecil (tidak erat)

0,40 - 0,70 Hubungan yang cukup

$0,70-0,90$ Hubungan yang erat

0,90 - 1,00 Hubungan yang sangat erat

Koefisien korelasi person

$\mathrm{d}=0,591 \times 100 \%$

$\mathrm{d}=\mathbf{5 9 , 1} \%$

\section{b. Taraf Kesalahan/Signicant}

Taraf kesalahan/signicant yang digunakan adalah 0,01 atau 0,05.

\section{c. Statistik Uji Hipotesis Daerah Kritis Penerimaan Ho atau Penolakan Ho}

Dari uji hipotesis (t hitung) didapat nilai sebesar 3,110 dan dibandingkan Dengan t tabel. Dengan taraf kesalahan/ significant $0,05 \mathrm{dan} \mathrm{dk}=20-2=18$ maka diperoleh nilai $\mathrm{t}$ table adalah 2,101. Ternyata nilai $\mathrm{t}$ hitung $=3,110$ lebih besar dari pada t tabel $=2,101$ dan sehingga $\mathrm{Ho}$ ditolak, artinya pengujian significant dan H1 diterima. Hal ini menunjukkan ada hubungan antara Peranan Audit Sistem Informasi Akuntansi Berbasis Komputer Dalam Penyajian Laporan Keuangan.

\section{KESIMPULAN}

Dari pembahasan yang penulis lakukan, maka penulis dapat melakukan kesimpulan sebagai berikut:

- Audit Sistem Informasi Akuntansi berbasis komputer merupakan suatu pemeriksaan mulai dari input sampai dengan output.

- Output diperiksa apakah Financial Report/output lainnya sesuai dengan standar yang ada. Proses pada Sistem Informasi Akuntansi berbasis komputer diperiksa apakah pemrograman menjamin kecepatan, ketelitian dan relevansi suatu informasi. Pemeriksaan dilakukan pada input yang dimasukkan tersebut valid atau tidak dan sesuai dengan ouput atau tidak. Audit Sistem Informasi Akuntansi berbasis komputer mempunyai peranan dalam Penyajian Financial Report. Sehingga Financial Report dapat dijadikan informasi bagi pihak intern maupun ekstern dan juga merupakan dasar pengambilan keputusan. 


\section{DAFTAR PUSTAKA}

Arrens \& Loebbecke. (1996). Auditing pendekatan terpadu. Jakarta: Salemba Empat.

Atmadilaga, D. (1994). Buku pintar panduan penulisan skripsi, tesis dan $\backslash$ disertasi. Bandung: Pioner Jaya.

Davis, G.B. (1999). Kerangka dasar system informasi manajemen. Jakarta: Pustaka Binaman Pressindo.

Echols, J. \& Shadily, H. (2000). Kamus Inggris Indonesia. Jakarta: Gramedia. Hall, J.A. (2001). Sistem informasi akuntansi. Jakarta: Salemba Empat.

Hartadi, B. (1999). Internal audit. Yogyakarta: Andi. Hasibuan, M. (2001). Manajemen: dasar, pengertian dan masalah. Jakarta: Bumi Aksara.

Ikatan Akuntan Indonesia. (2002). Standar akuntansi keuangan per 1 April 2002. Jakarta: Salemba Empat Patria.

Ikatan Akuntan Indonesia. (2001). Standar profesional akuntan publik per 1 Januari 2001. Jakarta: Salemba Empat Patria.

Jauh, K.L.J. Pengenalan komputer. Jakarta: Mutiara. Krimiaji. (2003). Sistem informasi akuntansi. UPP AMP YKPN.

Lapoliwa \& Daniel. (2000). Akuntansi perusahaan. Institut Bankir Indonesia.

Prasanti, H. (2004). Mengolah data statistic dengan menggunakan SPSS. Bandung: UNIKOM.

Sarwono, J. (2003). Metode penelitian pendekatan kuantitatif. Bandung: Bagian Penerbitan Lembaga Penelitian dan Pengabdian Kepada Masyarakat, UNIKOM.

Siamat, D. (1999). Manajemen lembaga keuangan. Jakarta: Fakultas Ekonomi, Universitas Indonesia. 